\title{
Spiritual safety nets and networked faith: The "liquidity" of family and work under late modernity
}

ISAAC GAGNÉ

\begin{abstract}
In the midst of the 20 years of economic and social uncertainty that has been punctuated by the worldwide financial crisis, an increasing rhetoric of economic uncertainty and social instability has risen to popular consciousness among many ordinary citizens in Japan. With changing economic and familial relations, individuals in Japan are participating in the networked communities of "moralizing institutions" to find renewed stability and a sense of empowerment in their lives. Through ethnographic fieldwork with an international religious organization and a domestic ethics organization, this paper analyzes the diverse ways in which individuals are reestablishing a sense of stability and direction by reengaging with idealized life patterns and family orientations that have become more elusive under the increasingly uncertain socioeconomic conditions. Specifically, I analyze how individual members were directly affected by what Zygmunt Bauman calls the "liquidity" of recent economic reforms including rising unemployment and late-career layoffs which had drastic repercussions on life planning and family relations. As human networks built from resilient networked faith, these moralizing institutions provide a different kind of logic of "liquidity" and "flexibility," allowing members to realize their idealized life plans and to navigate toward the solid ground of a stable work and family life.
\end{abstract}

Keywords: faith; family; work; liquid modernity. 


\section{スピリチュアル・セーフティーネット：後期近代における家族と 雇用の「流動性」}

$$
\text { アイザック・ガーニエ }
$$

世界的な経済危機も含め 20 年に及ぶ経済および社会不安の中、経済不 安、社会不安に関する数多くのレトリックが日本社会にも定着するよ うになった。経済および家族関係の変化に伴い、日本でも「モラル的 組織」(moralizing institutions) のネットワーク型コミュニティー に参加し、自分の人生に新たな安定感とエンパワーメントを求めよう とする人々がいる。

本稿は、国際的な宗教団体と国内の倫理団体を対象としたエスノグラ フィック・フィールドワークに基づき、こうした先の見えない経済不 況下で、個人個人が失いかけた理想的なライフパターンや「中流」と しての家族や雇用の在り方を見直し、様々な手段で人生設計（ライフ パターン）を調整し自らの安定感を生み出す過程を分析する。

長期不況が生み出した構造改革は失業率の上昇や雇用の不安を一層高 め、個人個人の人生設計や家族関係に甚大な影響を及ぼしたのであっ た。そのため本稿では、ジグムント ・バウマンのいうモダニティの 「流動性」が個々のメンバーにどういった直接的な影響を与えているか、 またどのように対応しようとしているかについて着目する。バウマン のいう経済のモダニティの「流動性」は、人間の象徵的また精神的な側 面にも「流動性」をもたらしていることが考察される。しかし、スピリ チュアル・セーフティーネットや人的ネットワークで成り立つ「モラ ル的組織」が提供する「流動性」は、経済不安定を生み出し、社会格差 を生む流動性とは異なり、精神面による柔軟性と弾力性があり、メン バーは自分たちの理想としている人生設計や家庭、安定雇用を別の手 段や方法で取り組み、また達成する柔軟性や可能性を与えているとい える。

\section{Introduction ${ }^{1}$}

After nearly two decades of post-bubble socioeconomic malaise, Japanese society continues to struggle with a shifting global economy, changing demographics and molten social foundations. From the surface, corporate policies are disintegrating, family structures are flowing apart and educational discipline is breaking down. Since the bursting of the bubble in the early 1990s, Japanese society was no longer able to ignore the reality of growing social and economic discrepancies, and this awareness sparked the increasingly popularized rhetoric of Japan as kakusa shakai [stratified society] or fubyōdō shakai [unequal society] (see Ito and Yamada 2007; Miura 2005; Satō 2000; Yamada 2004). This became further exacerbated with the worldwide financial crisis begin- 
ning in 2007, which brought the reality of economic hardship to all sectors of Japanese society.

These material and discursive conditions seem to place Japan squarely in the flow of what sociologist Zygmunt Bauman calls "liquid modernity." Liquid modernity refers to the increasingly uncertain, insecure and unsafe modern living conditions faced by both individuals and institutions. Under late modernity, as "power has become truly exterritorial," Bauman characterizes the new era as "the end of $[\ldots]$ mutual engagement: between the supervisors and the supervised, capital and laborer, leaders and their followers, armies at war" (Bauman 2000: 11; see also Bauman 2001). It is under such elusive power relations that Bauman posits that institutions challenged by contemporary socioeconomic conditions are no longer able to solidify reliable structures nor unite individuals, while the coherence of individuals' life courses are challenged by variegating references for life planning and lifestyles. Bauman predicts that such social and economic polarization within society will progressively enhance the level of individuation and privatization, leading to an "individuated society" and the "privatization of humanity" (Bauman 1998, 2000, 2001).

Fears of the liquidation of Japanese society flow from recent claims that Japan has lost its "new middle-class status" and has become a kibo kakusa shakai - that is, a society with socially marked differences in one's dreams for the future. Drawing heavily from Bauman, Japanese sociologist Yamada $(2004,2009)$ identifies such social and economic polarization in Japan and argues that there are increasing differences in individuals' future hopes in terms of education and future career success, resulting in the division of Japanese people into winners (kachi gumi) and losers (make gumi) who Yamada calls the "new poor." If Yamada's analysis holds then are growing social inequalities eroding long-standing shared postwar life aspirations or - as Bauman ventures hopefully - are Japanese individuals actualizing new identities and lifestyles and aspiring to new ideas of work and family?

Such widespread uncertainty under contemporary neoliberal economic reforms has produced a supply and demand for new institutions that fill the gap between the ideal and the reality by offering "new" techniques of liquid life planning, such as companies that facilitate reemployment like the national job placement service Hello Work and facilitate marriage hunting (konkatsu). Indeed, recent studies on single women's desires for children (Tanaka-Naji 2009) and the lives of single mothers (Hertog 2009) and working women (Nakamura 2006) show a renewed sense of a strong desire for stable family life. Similarly, in my fieldwork, it is precisely because some individuals were deeply affected by neoliberal economic conditions in Japan that they became highly 
aware of growing uncertainties on political, economic and social levels, and therefore reached out to each other through networked faith and human connections. As in the immediate postwar period, today some individuals are looking for new ways to fulfill desires of work and family through institutions other than the bubble-period hallmarks of home, schools and companies.

In order to locate the effects of larger structural challenges on the ground level, this paper focuses on individuals who chose to participate in what can be termed moralizing institutions, examining how these individuals live through and manage contemporary difficulties in their daily lives, including job instability as well as marriage and family problems. As a general term, "moralizing institutions" includes religious institutions and schools that have developed and grown throughout the postwar period in a variety of forms. Here, however, I use the term to refer to the specific kinds of spiritually inflected institutions that are classified together with "new religions" that have risen to prominence in the postwar period, but which unlike some forms of new religions focus more on interpersonal connections and thoughtful reflection than on ritualistic aspects.

Rather than analyzing moralizing institutions through their institutional history, doctrine and formal structure, this paper aims to unpack what is often dismissed behind the macro-institutional level of analysis. In other words, by examining the stabilizing effects of the informal and fluid exchange of economic, interpersonal and spiritual support that flows among members, this paper expands on the notion of "liquidity" under late modernity. Although the global conditions of liquid modernity challenge institutions and polarize society while at the same time alienating it, the ways in which liquid modernity is crystallized in individual ways of life does not generate a monolithic pattern. Instead of being a form of "networking" that relies mainly on "fragile and shortlived [...] communities of shared worries, shared anxieties or shared hatreds" (Bauman 2001: 50) - this new form of networking is rather built on shared hopes for idealized life patterns and a flexible faith that empowers members with the capacity to create trust in each other and the institution. By creatively combining their capital (i.e., networked faith and interpersonal connections) with the instability of contemporary society, the individuals introduced in this paper creatively recasted and fulfilled mutually shared life aspirations and ideals for work and family, sometimes even strengthening institutional ties and structures that might otherwise seem to be flowing apart.

Through ethnographic fieldwork with an international religious organization, the Japan Baha'i Network, and a Japanese ethics practice organization called Jissen Rinri Kōseikai, I describe how the institu- 
tional and cosmological differences of each organization - that is, "global and liberal" vs. "traditional and conservative" - engage with socioeconomic changes and facilitate (and in some cases reproduce) individual actions and desires. Furthermore, I explore the diverse ways in which individual members of these organizations recast attitudes toward work and family, revealing new possibilities for maneuvering through the socioeconomic challenges of twenty-first century Japan.

My analysis focuses on (i) a comparative institutional analysis of structural differences between globally oriented and domestically situated moralizing institutions in contemporary Japan; (ii) the specific ways in which both organizations, the Japan Baha'i Network and Jissen Rinri Kōseikai, and their members are responding to the larger social and economic changes in contemporary Japan; and (iii) how the combination of networked faith and interpersonal connections helps individuals make sense of diversifying ways of life while actualizing life aspirations and family ideals. In particular, this paper focuses on several case studies of members whose desires and actions illustrate more or less flexible attempts to deal with the intersection of unemployment, deferred marriage, family breakdown and the dissolution of the old middle-class model. Though these individual issues are not new in Japan or elsewhere, their increasing frequency as well as the increasing social awareness of them has called into question what had been taken as normalized life-stage events.

\section{Moralizing institutions in the twenty-first century}

The uncertainty and resignation of post-bubble, post-"Lehman shock" Japan is not entirely unprecedented and resonates with the notorious "exhaustion and despair" of the postwar period as well as subsequent debates about the social, economic and political future of Japan (Crystal 1965; Dower 1999). While opinions differed widely back then, there was a call for a distinct blend of spiritual and moral orientation and hope and, for a time, both were located and subsumed within the nationwide project of postwar reconstruction. By the 1960s and extending through the 1980s, mass affluence brought an idealized though not completely realized standardization in life expectations and orientations, if not in actual job security and lifestyles (see Ishikawa 1982; Kelly 1993, 2002; Vogel 1963).

Today, the double punch of the bubble bursting and the world financial crisis has not only pulled the rug out from under the economy but also snatched away the security blanket from many who felt the least threatened. For these individuals who face new periods of uncertainty not only at work, but also in the family and at school (Alexy 2007; 
Honda 2004; Kelly and White 2006), the panic inducing discourse of the media and the finger-pointing of the government do not provide the anchor that will create stability in their lives (see Yamada 2004). The orienting moral foundations and social fabric of what was once called the "mass of new middle-class" seems to many people to be unraveling.

In response, some individuals are crafting "new" directions in their lives within contemporary moralizing institutions. In scholarly and popular discourse, both of the organizations discussed here are categorized under the term shinshükyo [new religion] (Inoue et al. 1996). In this paper, however, I find it more accurate and productive to approach both as "moralizing institutions" in postwar Japan. In this way, I choose not to emphasize the particular modern characteristics and thaumaturgical aspects of contemporary religious institutions (see Davis 1980; Inoue 1997; McVeigh 1997; Shimazono 2001, 2004; see also Reader and Tanabe 1998 for their take on older strains of "this worldly benefits" in Japanese religion) or attempt to define the ambiguity of more recent "new spirituality movements" (see Shimazono 2007) and "spirituality booms" (Tsujimura 2008). Rather, I choose to follow my informants' ways of describing their involvement as a spiritually meaningful and personally fulfilling way of finding orientation and purpose in their lives. Informants in both organizations emphasized the inclusive and supportive nature of these kinds of institutions, citing the socially embedded human connections and universalist rhetoric (whether internationalist or traditionalist) as distinctive from what they see, more generally, as the ritualistic, exclusive, overly ideological and sometimes political characteristics of Japanese religious institutions. Ultimately, the moralizing institutions discussed here are by definition concerned first and foremost with providing direction and meaning in individuals' lives, a kind of orientation that extends beyond specific contexts and goals and wraps the individual together with other individuals, with other institutions, and within the world at large.

\section{The Japan Baha'i Network: "My calamity is my providence"}

The Japan Baha'i Network is a nationally diffuse organization with most recent official statistics estimating 3,000 members. ${ }^{2}$ It was legally recognized as a religion in Japan in 1956 but members have worked with Japanese religious groups such as Ōmoto-kyō since at least the 1920s in promoting religious universalism (Alexander 1977). Globally it is estimated that there are between five to seven million Baha'i members in over 200 countries. It is an entirely lay organization run by elected councils at local, regional, national and global levels. It is 
mostly self-organized and while there are local religious facilities most Baha'i gatherings are conducted at members' homes and are casual and open. The Baha'i faith advocates universal education, gender equality and international development, and works closely with global institutions like the United Nations.

Baha'i gatherings are often multi-ethnic and internationally minded, with primary activities consisting of study groups on the faith and discussions of local and global issues. As a result, the kinds of Japanese members who join these activities are often intellectually curious and economically comfortable. In recent years, however, more and more members are coming from less educated and less stable backgrounds, adding new needs and perspectives to Baha'i activities. Formal and informal interviews and participant-observation with a core group of 18 members (eleven women and seven men, with an average age of mid-30s) over the past four years revealed that the socioeconomic level of most members tends toward upper-middle class. Half were employed in major corporations and the remainder evenly distributed among selfemployment, NGOs, small companies and the retired. Over three-quarters $(83 \%)$ had education beyond high school, with $61 \%$ holding a four-year degree. About one-fifth $(17 \%)$ had been laid off in the past two years, $17 \%$ were in different stages of "freeter-ism" (short-term jobs), and $17 \%$ were in companies facing downsizing and restructuring.

\subsection{Shibamata-san: From jobless single to married professional}

On April 4, 2010, a beaming Shibamata-san was married in a small ceremony at the Tokyo Baha'i Center surrounded by close family and around 30 Baha'i friends. Her new husband was Gunther, an Austrian man who had flown in from Europe for the wedding. Just six months earlier, Shibamata-san had been jobless and single, out of work since early 2009 and uncertain of where to go in her life. With a positive attitude and professed faith in prayer and the Baha'i teachings, together with the emotional and material support of her Baha'i friends, a year after her sudden ill luck Shibamata-san was employed as a fulltime worker (seishain), married, and preparing for her husband's move to Japan.

Shibamata-san was born to middle-class working parents in northern Kyushu in the late 1960s, the eldest of two daughters. Her sister married an American man and became Baha'i through friends in rural Kyushu. Originally skeptical of it as a "strange religion," after her sister became Baha'i, she attended a "social night" and became friends with several members. While having been critical of religions like Christianity in the past, because the teachings of the Bible "didn't have any 
connection with [her] daily life," Shibamata-san "signed up" to become Baha'i in 2006, within six months of first participating in the community.

In early 2009, after having being affected by the Lehman shock, the real-estate company that Shibamata-san had worked for was going under. The company provided its employees with the option of either taking early-retirement and leaving voluntarily or continuing to work with an uncertain future. After consulting with older Baha'i members, Shibamata-san took this sudden hardship as an opportunity, embracing the Baha'i maxim "My calamity is my providence," and accepted the early-retirement money with an uncertain future.

As a recently unemployed women in her early 40s, Shibamata-san was living alone in Tokyo and also beginning to doubt that she would have a chance for marriage. She began attending study groups and prayer meetings at the Baha'i Center twice a week, even becoming a facilitator for one Friday evening study group for young students and self-employed Baha'i members. She also began saying a particularly "potent" Baha'i prayer for assistance regularly, seeking direction. At one point she was even promised employment at a company run by a Baha'i acquaintance of hers, but as the shock waves of the economic crisis continued to spread, this company was unable to hire new employees. By mid-October, much in her life was still uncertain.

At a gathering in late October, there was a sudden change. At a friend's wedding, a woman she had just met offered her a full-time job working for the real-estate division of one of Japan's largest banks. In preparation for the job she studied for her book-keeping license through the government-sponsored Hello Work program and took courses to improve her English. With the money she had saved from early retirement she took a month-long trip through Europe. Shibamata-san took full advantage of her Baha'i human network as well: while traveling across Europe she stayed with Baha'i friends in London, Paris and lastly Belgium, where she reconnected with an Austrian man - a friend of a friend she had gotten to know the previous year. Though a part-time Protestant minister himself, the two felt a closeness with each other's deep spirituality and similar stages of life, and by the time Shibamata-san returned to Tokyo she was engaged to be married.

Relating these experiences with a smile, she spoke of the power of prayer and God's assistance in this turn of fortune. Thanks to God's blessings, she said, she had been able to make the right choices as within months of taking early-retirement, her old company went bankrupt and the remaining employees were left jobless with no compensation at all. At each step of the way on her "journey" through the hard- 
ships of being single and unemployed and the joys of marriage and reemployment, her close friends in the Baha'i community had encouraged her with emotional support and constant prayers for well-being.

\subsection{Pluralities of membership: Human networks and a resilient faith in God}

Shibamata-san's story is surprisingly common among Japan Baha'i Network members I have met during the past ten years. From sudden unemployment to educational retraining to a later-life international marriage, Shibamata-san's story encapsulates a range of new ways of life and changing opportunities in contemporary Japan. It highlights the ways in which faith in God and the physical and emotional support of fellow believers - sometimes family by blood, sometimes family in spirit - offer members both a sense of direction and purpose in their lives as well as an actual network of assistance in times of need. More interestingly, Shibamata-san's story also points to deeper commonalities in the hopes and desires of Japanese society at large, hopes and desires that also exist beyond the Baha'i community and its particularities. Faced with a future alone and jobless, Shibamata-san took the initiative in her own life to find the dream of stability she always yearned for: a stable job - in a major Japanese corporation no less - and a happy marriage, built on a shared faith in God if not the membership in the same religious organization.

Shibamata-san is not alone in her desires and experiences. While at first her international marriage and reemployment might seem to be emblematic of a new direction in Japanese society, the international and liberal-mindedness of the Japan Baha'i Network in fact facilitates a means for achieving such common desires of happy marriage and employment. Another informant, Yokota-san, who married a Swedish Baha'i man, similarly seemed to be breaking the mold of traditional life paths. Over the four years of our acquaintance, however, the events leading up to her marriage revealed deep-rooted family problems and the deeper concern for a like-minded stable partnership which eventually led to her marriage. Disowning her parents because of domestic discord, she left for Tokyo from Shikoku and spent several months living in the house of her "spiritual parents" (Baha'i mentors) in Tokyo until she found a place of her own. A long-term relationship with a non-Baha'i Japanese fell apart due to what she described as his fundamental disinterest in raising children in the Baha'i faith. After several months of courting a Swedish Baha'i, she finally married him, and their first child was born one year later. In both Shibamata-san's and Yokota-san's cases, their seemingly "new" family structures were very 
much born out of a yearning for a stable family life, an ideal that was made even more difficult - and thus even more desirable - within the current moral crisis of family discord and unstable marriages.

As these two stories show, the Japan Baha'i Network provides a nexus of religious and personal faith along with individual and social life. As a lay organization, each member has a life outside of the group as well as within the community. It is also a space where both personal issues like Shibamata-san's worries and social issues like the loss of safety and neighborly communication in Japan can be confronted and reflected upon. Aided by its socially and intellectually engaged demographics, the Japan Baha'i Network is thus also a venue for conversation on social issues and a place for intellectually (and internationally) inclined individuals to engage in debates on a range of theological and practical issues in the faith as well as global issues affecting the international community.

The international and multi-cultural character of the Baha'i faith creates a network which either directly or indirectly connects nearly every member of the Japan Baha'i Network to a broader human network and a spiritual worldview, both of which extend beyond Japan. Some members in Japan are ethnically non-Japanese, who either moved to Japan as "pioneers" (missionaries) or were born in Japan to pioneer parents. There is also an increasing number of biracial Japanese members among the second and third generations, and the majority of second-generation members in the Tokyo area are in international marriages. The international orientation of the faith is also apparent in the kinds of Japanese members who join; many have spent years abroad in Australia, Southeast Asia, the U.S., Canada and the Middle East, where they encountered Baha'is for the first time and later became members themselves. True to its name, the Japan Baha'i Network provides a network for finding an instant community in whatever country one may travel to, with a ready source of friendship, fellowship and resources available.

On a practical level, the resources of the Japan Baha'i Network as an internationally and socially embedded institution can take a very material form for members in need like Shibamata-san. Many Baha'i members in Japan are self-employed or entrepreneurs of one kind or another while others are well-educated, high level executives, and thus they are often able to offer jobs to other members or at least help find employment opportunities. In one case, a Baha'i man from New Zealand secured a two-year job as a financial analyst for a Japanese Baha' $i$ with a single phone call. Likewise, Otani-san, a young Japanese Baha'i woman was given employment at an international daycare facility run by a Baha'i in Tokyo. Kato-san, another young Baha'i Japanese woman 
who was searching for "meaningful employment," was given a job as a full-time caretaker of the Baha'i office in Tokyo with her husband, a Baha'i from the Pacific Islands.

In addition to such direct employment, Baha'i members in Japan are also active in indirect networking assistance: Kawakami-san, a selfemployed Japanese woman, for example, volunteered to help two Baha'i students from Hong Kong who recently arrived in Japan to find part-time jobs, connecting them with potential employers, providing references, helping them prepare for interviews, and even reviewing and editing their résumés. Kawakami-san has also found success in her own career as an architect by connecting with the United Nations and international investors through Baha'i friends. Beyond work-related networking, Baha'is also attempt to extend their interpersonal networks to provide lodging (as in Shibamata-san's case in Europe or Yokota-san's case in Tokyo) and host-families for acquaintances, including non-Baha'is. Though certainly not always successful, these Baha'i networks put their rhetoric of internationalism into practice by connecting and assisting Baha'is across Japan and around the world, wrapping their members together in a shared sense of struggle and support that seeks to transcend borders and cultures.

The Baha'i faith seems to provide more than just institutional and material aid to members. In the face of difficult economic conditions, members liberally deploy Baha'i teachings to argue for a "harmony between the material and the spiritual," particularly using quotations from two holy texts (Abdu'l-Baha 1918; Baha'u'llah 1982 [1963]). Especially for members living in Japan, where a high cost of living combines with active consumerism, questions of materiality and spirituality as well as of how to conduct business and consume leisure in an ethical fashion are frequent issues raised in discussions and study circles; at one study circle an informant promoted a recent book by a Baha' $i$ economist (Garis 2007) that describes how to build an economic system on spiritual principles. Such works provide a foundation for Japanese Baha'is both in running their own businesses and in looking for work that they feel will contribute to society (shakai ni kōken suru).

In addition to seeking to harmonize the spiritual and the material, Baha'is actively promote an international and cosmopolitan spiritual worldview that teaches members to seek "unity in diversity" and to work at the local community level in order to bring change on a global scale. In researching the Baha'i community in a southern U.S. city, McMullen (2000) describes a global consciousness combined with local activism, what he calls "situated universalism." In Japan, too, Baha'is employ this situated universalism to understand global problems like the financial crisis, the loss of community and religious wars through 
local lenses of a loss of personal human connection and trust as well as the "decadence of Japanese materialism" that has bred a dog-eatdog society (kyōsō shakai). Until recent years, Japan's economic success had in fact been one of the biggest hurdles for Baha'is in Japan; some members spoke of the difficulty in spreading their message in Japan precisely because of the general degree of affluence which made it more difficult to gain new members than in countries with greater disparities of wealth. Today, however, economic issues have become a renewed source of struggle for members both new and old. As such, recent Baha' $i$ "outreach" is often "situated" on the personal level of providing a space for reflection and discussion about daily struggles while at the same time it is "universalist" in the members' discussions which try to connect personal stories of family trouble or company problems to the broader issues underpinning the social and economic malaise of contemporary society.

On this personal level, the Baha'i teachings aim to encourage each individual to accept all difficulties they face in life as challenges "sent by God" to make them stronger as individuals and as Baha'i members. Katori-san, an upper-level female manager for an international financial company, found hope in her unwavering faith in God when faced with sudden unemployment as a direct result of the Lehman shock. She saw it as a hidden gift from God to focus more on her family and to improve her own credentials; she is now studying for law school while working at a company that demands less hours. Similarly, the power of prayer has become a frequent topic in Baha'i discussions during the last two years of financial difficulty. Most recently, Kaneda-san, a non-Baha'i man, lost his job at a "conservative" Japanese company and found reemployment at a multinational insurance company after "one month of daily prayer." Not only was it a more "liberal" workplace but he also claimed it contributed to society by "selling people safety" in the form of life insurance. While the power of prayer alone did not change his circumstances, it changed his perception of his circumstances, and tested his faith to find strength in adversity and to accept all misfortune as "another face of God's love" and as a "gate to greater happiness."

In deploying the Japan Baha'i Network's combination of interpersonal networks and spiritual assistance, the orientation of members' life courses reflects familiar dreams and desires of family, work and lifestyle that have been rebuilt throughout the postwar period, even if their particular content might have changed to include "spiritual families," international marriages, job-changing and religious work. Nonetheless, the "rhetoric of finding personal spiritual strength and the sense of warmth" that members speak of give many a sense of purpose 
in their lives and provide a logic of liquidity - a flexible way of interpreting both personal and social events as part of God's plan - that enables members to find meaningfulness in the "trials and tribulations" of modern life.

\section{The Jissen Rinri Kōseikai: "The gate to happiness is through hardship"}

Jissen Rinri Kōseikai is based in Tokyo and is recognized by the Ministry of Education as a "social education organization." Conservative estimates suggest a membership of 2,500,000 nationwide, with upper estimates from members claiming as high as $4,400,000 .{ }^{3}$ Though its roots stretch back to the founder's involvement with a new religious movement in the pre-war period, the founder broke with the original organization and pursued the rebuilding of Confucian-based morality and ethics in what he saw as the morally devastated postwar Japanese society, premised on a social role-based vision of the "natural order of nature." The founder's son is the current head of the organization, and their main office is located in central Tokyo, where it also serves as the workplace for hundreds of full-time workers for the organization. Aside from publishing books by the founder and his son, the organization is also closely tied with local and national politics of diverse parties, with many Diet members in attendance at their major events.

Members of Jissen Rinri Kōseikai are largely middle and lower-middle class, with the average age of members around their mid-40s. It is almost entirely domestically oriented with very few non-Japanese participants. According to Numata (1988) and my own fieldwork at weekly meetings over the course of twelve months, roughly $75 \%$ of active members are middle-aged housewives (sengyōshufu), who mainly attend daily early-morning meetings and pay door-to-door visits to distribute the organization's publications and encourage new membership. Though nearly all of the active male participants I encountered had some degree of tertiary education, the lives of many remained along the model of the old-middle class - that is, self-employed or working in small companies. In contrast, many of the female members had no tertiary education and represented the "new middle class" - married to salaried employees of large or medium-sized companies. Interestingly, Numata (1988: 275) notes that most male members during the 1980s spoke of difficulties in interpersonal relations (ningenkankei) at work. In 2009 and 2010, however, nearly all male members spoke of economic difficulties at their workplaces. The most common topics for female members were putting up with their husbands' resistance to 
their participation in the group and fears about raising their children correctly in a "chaotic and uncertain society" - two perennial issues for female members - with the additional fear of their children growing old unmarried.

\subsection{Kagami-san: The ethics of family business}

Even in the postwar national affluence of the economic miracle, the rapid rise of the "new middle class" of salaried workers and the fast urban development in Japan was not without its victims, many of whom were members of the "old middle class" of merchants and family business owners (see Bestor 1989; Kondo 1990). Kagami-san, a balding, stout man in his 60s, was a second-generation proprietor of a small gourmet foods store in northwestern Tokyo that he ran with his wife and son, a single man in his early 30s. Every day, together with his wife, Kagami-san came to the early-morning Jissen Rinri Kōseikai meetings without fail, occasionally accompanied by their son. Two of their three daughters who live at home but "who were in a period of resistance" never came to meetings and seldom featured in our conversations. For Kagami-san, the symbolic and managerial head of both the business and the family, the early-morning meeting speeches were his chance to reflect on social and family issues, to expound on his business philosophy and the ethics of business, and every so often to make direct and almost ideological statements about family and business to his wife and son sitting in the audience.

Both Kagami-san and his wife are second-generation members; and as a private business owner who also made daily trips to the Tsukiji fish market, Kagami-san naturally worked on an early-to-bed and early-torise schedule that facilitated attendance at the 5 a.m. ethics meetings. Beyond this physical predisposition for participation, however, Kagami-san's speeches also made clear the importance of this space for harmonizing his work with his family by binding both through the ideological teachings and logic of morality promoted by the organization. With an emphasis on shujin chüshin [i.e., the husband as the center of the family] the teachings of the ethics group automatically gave Kagami-san a privileged role vis-à-vis his wife and children, a role that was enforced by being the manager of his own store.

More than an ideological support, Jissen Rinri Kōseikai was for Kagami-san the very centripetal nexus of family dynamics and business relations. Amidst the hardships of disappearing local shopping avenues (shotengai), the encroachment of convenience stores, and the prolonged recession, not only was it hard for a small shop like his to stay afloat, it had become even harder for such shops to be passed on to 
willing children as a family business. As Kagami-san spoke of his passion for work, he would also decry his son's lack of passion while simultaneously saying how lucky he was to be able to sit in the audience and listen to his own son's speeches on occasion. His wife, in turn, would speak of her own difficulty in being completely obedient to her husband, "as she should be," but she also would not fail to put her own spin on family events, often drawing laughter from the largely female audience.

Kagami-san's son, for his part, would speak of his own fears of a lack of confidence but also his renewed respect for community and family. In 2009 he had become more active in the local neighborhood shop association (chōnaikai) and had also grown to appreciate the value of local festivals (matsuri) as well as the neighborhood Shinto deity (ujigami). At times he spoke of how he used to believe that he would live his life in his own way (jibun rashiku), but now he had decided to make a "course correction" (kidōshūsei) in his life and hoped to take over the shop from his father and continue the business in the future as the third-generation proprietor.

\subsection{Inculcating the natural order: Raising a family, upraising society}

For the Kagamis, Jissen Rinri Kōseikai's teachings and meetings overlap nearly completely with their family and work. Faced with economic hardship and the moral crisis of collapsing families, their memberships and participation as a family can be interpreted as serving as a safety net that binds them together as a family in so far as the organization's network of human interrelationships binds each member together ideologically within the broader web of the organization's membership structure. This triple bind - as family, as business, and as members is an anchor of stability as well as an unorthodox method of maintaining the familial and business structure of "middle class" life. Even the absence of their daughters at most meetings was not interpreted by the ethics group or the family as a sign of them drifting away from the family, but rather as a natural but temporary stage of "resistance" to the ethics group - a stage that all members including all three Kagamis mentioned in their morning speeches. While the Kagamis are a particular example of success as an "ethics family," the issues that they struggle with, including economic uncertainty and family pressures, are representative of the genuine concerns of both members and nonmembers alike and are the most compelling reasons that many members seek out or accept the moral logic and human relationships offered by Jissen Rinri Kōseikai. 
As an institution, Jissen Rinri Kōseikai is a "traditionalist" hierarchical and Confucian-based organization that emphasizes "accepting things as they are" - much like the Japan Baha'i Network. In contrast to the "liberal" nature of the Baha'i faith, however, those who participate in Jissen Rinri Kōseikai with a critical attitude or a lack of overt enthusiasm are harshly criticized, whereas members who are obedient and outwardly positive are praised and find their responsibilities and status in the group rise rapidly. For many members, at least $75 \%$ of whom are full-time housewives or self-employed women (by my own calculations from attendance at meetings), the organizational practices offer status and roles unavailable in other spheres of their lives at home, at work or in the community, giving many a chance to practice public speaking, organize meetings and give guidance to other members.

Actual networking among Jissen Rinri Kōseikai members takes a mixed form of direct material assistance, indirect career networking and direct employment. For many second-generation members, the long-term networks forged among members and with well-respected members known as "ethics counselors" can even assist them in finding marriage partners. This was also the case for Matsumoto-san who had lost his father at a very young age. His mother was an active member and sought advice from Kondo-san, an ethics counselor. As a young man, Matsumoto-san became skeptical of the organization and deliberately chose to go to a university far from home. After spending a decidedly "unethical" four years in college, however, he longed for the "comfort and direction" of the ethics group. He resumed attending the morning meetings and even became a full-time worker at the organization's Tokyo office thanks to Kondo-san's recommendation. In those early years, his boss protected him by instructing him personally and professionally, advising him to work "single-mindedly" without thinking of anything else, including possible romance.

For the next five years Matsumoto-san did exactly as he was told. Upon reaching his mid-30s, however, his coworkers started worrying about him still being single. Ironically, his boss even scolded him for not doing anything for his future, saying that it was time he seriously looked for a wife. Matsumoto-san confessed that he was interested in a female office worker, Ishiyama-san, who was also single and a secondgeneration member. After graduating from a two-year college in the mid-1990s and faced with no attractive job opportunities, Ishiyama-san had begun working at the Tokyo office in hopes of using her English to work for one of the affiliated international foundations. Though the job did not turn out to be a conduit to international work, it did guide her to "achieving another life goal" of domestic stability. It turned out 
that Kondo-san was also a counselor for Ishiyama-san's family and thus told Matsumoto-san to be patient while he took care of things. After receiving affirmation from Ishiyama-san, they waited for two months before receiving the blessings of Kondo-san and their superiors and then completed their marriage plans based on their superiors' schedules.

Their marriage, while seemingly a model of "postwar domesticity" with a full-time working man and a stay-at-home wife with a young child, conceals the "non-traditional" pathways of contemporary life choices that led to it, including a single-parent household, a young woman with dreams of using her English to work on the international stage, and an almost fatherly "ethical counselor" who guided both partners.

Stories like these abound within Jissen Rinri Kōseikai, many of which can be found within their monthly organizational magazine. It contains reports of family struggles and how to overcome them; and in recent years, in particular, there have been many reports of economic hardships, where families struggling with debts or unemployment report receiving food and donations from other members. In addition, the magazine includes many stories about the recent economic downturn in which those out of work find new jobs through members whom they met at the organization's morning meetings. For a limited number of truly devoted members, who often are second or third-generation like Matsumoto-san, the teachings of Jissen Rinri Kōseikai can even translate directly into career opportunities in the form of full-time positions within the massive organization, including clerical and managerial services at the Tokyo headquarters or at one of the many subsidiaries and research groups.

Ideologically, Jissen Rinri Kōseikai is close to the Baha'i emphasis on the practical effects of belief and sincerity. Though it eschews religious language, the organization pronounces a direct connection between an individual's internal state and his or her experiences in the world. As a cosmology it lacks the theological orientations of a belief in an omnipotent and loving God; nonetheless, the emphasis on "the providence of Nature" (daishizen no setsuri) and "natural laws" provides at best an optimistic outlook and at worst a benign future-oriented moral directionality that teaches individuals to "change their hearts and minds" in order to change their circumstances. Here, fulfilling "natural" social roles is the key to escaping suffering of all kinds. Difficulties at work such as job loss or interpersonal friction are interpreted as an individual's own shortcomings in fulfilling their social role as an employee or a coworker. This is also reflected on a national level, in so far as a country's success or failure (at war or economically) is directly corre- 
lated with how well that country has aligned itself to the "natural laws" of the world.

More than offering a "realizable" way of practicing ethics in everyday life, Jissen Rinri Kōseikai offers a moral worldview with the laws of nature paramount and the world of humans as but a small part of a "greater cycle." To participate in this cycle, there is no need for ritualistic faith-healing, spiritual practices or a separation from society in communes. Similar to the Japan Baha'i Network, the "key to happiness in this life" for members lies in the alignment with the "greater order of the universe" - be it God's or Nature's - and it welcomes members of all faiths and ethnicities; so long as they orient themselves along the moral compass of the group's worldview and the ethical bearings of the leader in their everyday lives. Unlike the progressive and international character of the Japan Baha'i Network, however, the daily ethical practices are structured along traditionalistic Confucian social roles; and by virtue of these teachings and the human network of its members its message tends to spread along the bicycle paths and Parent-Teacher Associations of the female members, as well as the neighborhood shop associations of its moderately educated and largely lower-middle and old middle-class members.

\section{Conclusion}

The two contemporary "moralizing" institutions dealt with in this paper, the Japan Baha'i Network and Jissen Rinri Kōseikai, differ greatly in their history, structure and doctrine. Appealing to progressive internationalism on the one hand and Confucianist traditionalism on the other, both institutions provide diverse pathways for individual ways of life that make use of a network of "shared hope" and a method of interpreting individual difficulties. Furthermore, whether they use the language of "God and prayer" or of "natural laws and daily ethics," both provide faith in overcoming contemporary hardships through changing oneself and changing one's perceptions. As moralizing institutions that crisscross the spheres of family, school and work, they also support existing rhetorics of family and society while offering alternative avenues of re-contextualizing them by offering particularized pathways to normalized life stages of marriage and employment.

As in many societies around the world, moralizing institutions like these provide members with ways of coming to grips with the increasingly elusive "middle-class" hope of a stable life which, though it was largely illusory for most people in the past, was comforting in its realizable potential nonetheless. Over the past 20 years in particular, the widespread popularization of fears of socioeconomic stratification and 
inequalities, of delayed marriage and non-marriage, as well as of family breakdown have given these realities a powerful discourse that has been picked up by scholars, popular media and average citizens alike. At the same time, as the case studies in this paper have shown, despite far-reaching social stratification due to a combination of socioeconomic reforms, demographic shifts and individual perceptions, individual desires for family and life orientations have not been subverted by the "liquidity" of ever uncertain dominant socioeconomic conditions.

To this end, many of Japan's moralizing institutions offer flexible pathways via human networks and faith that slot into new life stages (and consciousness) of job loss and economic struggles at work, deferred marriage and family breakdown. For individuals like Shibamatasan the very "new" opportunities of the Japan Baha'i Network's international networks and a faith in a universal(ist) God helped her to find stable work and a marriage partner - in many ways the postwar "ideal" for many women in Japan - just at the moment in her life when she feared she would never have either. For Shibamata-san, Yokota-san and Matsumoto-san as well, their seemingly "new" paths to marriage also belied incredibly brief courtship periods and, in the latter two cases, relatively rapid childbirth thereafter that provocatively echoes the family dynamics of "defunct" arranged marriage practices. And for the Kagamis, Jissen Rinri Kōseikai has given them a space for reflecting on the struggles of an old family business in the new socioeconomic order, with the husband preaching to his family, the wife complaining about the husband while also binding him closer, and the son finally expressing his determination to change his life and accept the "old middle class" values of his parents' generation.

As Bauman (2000) predicted with his concept of "liquid modernity," the diversity of pathways to the kind of life idealized by so many both within and outside of these moralizing institutions is perhaps one of the most compelling marks of what the particular conditions of twentyfirst century socioeconomic uncertainty have brought to Japanese society. However, flexible pathways born out of "liquidity" in modern life conditions did not simply variegate or erase individuals' future hopes and desires (kibō kakusa) in terms of education and career success. Instead, the desire for an anchored "mainstream" life pattern in the midst of a Japan buffeted by global flows remains as strong as or stronger than ever and it is individuals who actively use such liquid pathways to achieve "stability" in their life. ${ }^{4}$ Much recent academic writing has highlighted discrepancies between desired ways of life and actual circumstances, such as Tanaka-Naji's (2009) analysis of the disjuncture between desires and practices of childbirth and Hertog's (2009) exploration of women who "found themselves" as single moth- 
ers but who still felt marriage was an attractive choice - despite infidelity that often left them in that position. Similarly, Nakamura's (2006) study found that even as women's participation in the workplace increases, so too does the continued view of the workplace as the ideal place for finding marriage partners. The case studies presented in this paper show that the multiple pathways to fulfilling desired life patterns and coping with the increasing uncertainty in socioeconomic conditions do not simply assure increasing individuation or privatization of desires and institutional distrust in Japan.

The condition of liquid modernity no doubt deterritorializes power relations and conditions by challenging and sometimes undermining institutions of work and family and, thus, potentially capsizing an individual's life-course. However, it does not necessarily transform individual consciousness toward such institutions, whether it is a stable company or a desired family. The desires and choices of action by members of the organizations analyzed here are of course both gendered and socioeconomically structured by virtue of their income, education and family structures, especially as they produce second-generation members and because members return to the organizations during different stages of their lives. Nevertheless, the remarkable similarities in their underlying faith - that is, that individuals are responsible for their own fate and can transform it through prayer and everyday actions, and the fact that certain institutions can help them do this - points to deeper continuities in both Japanese religion and Japanese society more generally which resonate within today's increasing ideology of self-responsibility, opening up fluid pathways of personal development despite shifting socioeconomic foundations.

Isaac Gagné (isaac.gage@yale.edu) is a Ph.D. candidate in sociocultural anthropology at Yale University, and is currently completing his research on the intersection of faith, morality and ethics in everyday life in contemporary Japan. His research interests include morality and ethics, religion and globalization, new religious movements, as well as youth and subculture in Japan. Past research includes gender and language use in a Japanese youth subculture.

\section{Notes}

1. The names of all individuals are pseudonyms to protect the privacy of my informants. I would like to thank the members of each organization for their cooperation and fellowship. My research was made possible through grants from the Japan Foundation, Fulbright-Hays and the Yale Council on East Asian Studies.

2. See Inoue et al. (1996). Members verified this in 2008, but told me that active membership was closer to 2,000 . If this figure is accurate, membership has not 
significantly changed over the past 15 years, unlike in many other "new religion" organizations.

3. These numbers are difficult to verify because reporting membership is entirely voluntary. Numata (1988: 262) reported over 3 million members as of 1987. Averaging high and low current estimates gives 3,450,000 members. Like the Japan Baha'i Network, this points to a relatively stable membership based on self-reporting, though the number of consistently active members is certainly far fewer.

4. Indeed, a recent poll by the Japan Productivity Office reported that $57.4 \%$ of new company entrants wanted to work at their present company for their entire life - the highest since the poll began in 1990 (Yomiuri Online 22 April 2010). This suggests that the "old" system of life-time employment now seems to have become an even more attractive ideal.

\section{References}

Abdu'l-Baha ibn Baha'u'llah. 1918. Some answered questions collected and translated from the Persian of Abdu'l-Baha. Chicago: Baha'i Publishing Society.

Alexander, Agnes Baldwin. 1977. History of the Baha'i faith in Japan 1914-1938. Osaka: Baha'i Publishing Trust.

Alexy, Allison. 2007. Deferred benefits, romance, and the specter of later-life divorce. In Peter Backhaus (ed.), Familienangelegenheiten [Family affairs] (Japanstudien 19), 169-188. Munich: Iudicium.

Baha'u'llah. 1982 [1863]. The Kitabi-i-Iqan: The book of certitude. Hertfordshire, England: Popper \& Co. Ltd.

Bauman, Zygmunt. 1998. Work, consumerism and the new poor. Philadelphia, PA: Open University Press.

Bauman, Zygmunt. 2000. Liquid modernity. Cambridge, UK: Polity Press.

Bauman, Zygmunt. 2001. Individualized society. Cambridge, UK: Polity Press.

Bestor, Theodore. 1989. Neighborhood Tokyo. Stanford: Stanford University Press.

Crystal, Edwina Mora. 1965. A study of cultural factors influencing moral and spiritual education in schools of Japan. New Jersey: Kean University MA thesis.

Davis, Winston B. 1980. Dojo: Magic and exorcism in modern Japan. Stanford: Stanford University Press.

Dower, John. 1999. Embracing defeat: Japan in the wake of World War II. New York: Norton \& Company, Inc.

Garis, Dalton. 2007. Manna from heaven: From divine speech to economic science. Oxford: George Ronald Pub Ltd.

Hertog, Ekaterina. 2009. Tough choices: Bearing an illegitimate child in contemporary Japan. Stanford: Stanford University Press.

Honda, Yuki. 2004. The formation and transformation of the Japanese system of transition from school to work. Social Science Japan Journal (Institute of Social Science, University of Tokyo) 7 (1). 103-115.

Inoue, Nobutaka. 1997. Shinshūkyō no kaidoku [Deciphering new religions]. Tokyo: Chikuma Shobō.

Inoue, Nobutaka, Michihito Tsushima, Shigeru Nishiyama, Mitsugi Kōmoto \& Hirochika Nakamaki (eds.). 1996. Shinshūkyō kyōdan/jinbutsu jiten [The encyclopedia of new religious organizations/figures]. Tokyo: Kobundo.

Ishikawa, Akihiro. 1982. Misekake no chūryū ishiki [Facade of middle stream consciousness]. In A. Ishikawa, T. Umezawa, Y. Takahashi \& T. Miyajima (eds.), Misekake no chūryū kaikyū: Toshi sarariman no kōfuku gensōo [Facade of middle class: City businessman's happy fantasy.] Tokyo: Yuhikaku. 
Ito, Mamoru \& Masahiro Yamada. 2007. Kakusa shakai supairaru komyunikēshon de nikyokukasuru shigoto, kazoku [Spiral of class society: Polarized work and family through communication]. Tokyo: Yamato Shobō.

Kelly, William. 1993. Finding a place in metropolitan Japan: Ideologies, institutions, and everyday life. In Andrew Gordon (ed.), Postwar Japan as history, 189-216. Berkeley: University of California Press.

Kelly, William. 2002. At the limits of new middle class Japan: Beyond "mainstream" consciousness. In Olivier Zunz, Leonard Shoppa \& Nobuhiro Hiwatari (eds.), Social contracts under stress: The middle classes of America, Europe and Japan at the turn of the century, 230-254. New York: Russell Sage Foundation.

Kelly, William \& Merry White. 2006. Students, slackers, singles, seniors, and strangers: Transforming a family-nation. In Peter Katzenstein \& Tadashi Shiraishi (eds.), Japan and Asia: The dynamics of East Asian regionalism, 62-83. Ithaca: Cornell University Press.

Kondo, Dorinne K. 1990. Crafting selves: Power, gender, and discourses of identity in a Japanese workplace. Chicago: University of Chicago Press.

McMullen, Michael. 2000. The Bahá'í: The religious construction of a global identity. New Brunswick, N.J.: Rutgers University Press.

McVeigh, Brian. 1997. Spirits, selves and subjectivity in a Japanese new religion: The cultural psychology of belief in Shukyo Mahikari. Lewiston, NY: E. Mellen Press.

Miura, Atsushi. 2005. Karyūshakai: Aratana kaisō shudan no shutsugen [Downstreaming society: Emergence of a new social class group]. Tokyo: Kobunsha.

Nakamura, Mayumi. 2006. The female-dominated path and attainment of marital status for Japanese women. In René Haak (ed.), Arbeitswelten in Japan [How Japan Works] (Japanstudien 18), 85-110. Munich: Iudicium.

Numata, Kenya. 1988. Gendai nihon no shinshūkyō: Jōhōka shakai ni okeru kamigami no saisei [New religions in contemporary Japan: The rebirth of the gods in an information society]. Tokyo: Sōgensha.

Reader, Ian \& George Tanabe. 1998. Practically religious: Worldly benefits and the common religion of Japan. Honolulu: University of Hawai'i Press.

Satō, Toshiki. 2000. Fubyōdō shakai Nippon [Japan, the unfair society]. Tokyo: Chuöshinsho.

Shimazono, Susumu. 2001. Posutomodan no shinshūkyō: Gendai Nihon no seishin jôkyō no teiry $\bar{u}$ [New religions in the postmodern era: The currents of contemporary Japan's spiritual conditions]. Tokyo: Tokyodō Shuppan.

Shimazono, Susumu. 2004. From salvation to spirituality: Popular religious movements in modern Japan. Melbourne: Trans Pacific Press.

Shimazono, Susumu. 2007. Supirichuariti no kōryū: Shinreisei to sono shūhen [The spirituality boom: New spirituality and its peripheries]. Tokyo: Iwanami Shoten.

Tanaka-Naji, Hiromi. 2009. Stated desire versus actual practice: Reviewing the literature on low fertility rates in contemporary Japanese society. Japanese Studies 28 (3). $415-430$.

Tsujimura, Shinobu. 2008. Religion in a consumer society: In the shadow of spirituality. Bulletin (Nanzan Institute for Religion and Culture) 32. 40-54.

Vogel, Ezra F. 1963. Japan's new middle class: The salary man and his family in a Tokyo suburb. Berkeley: University of California Press.

Yamada, Masahiro. 2004. Kibō kakusa shakai [Hope-differentiated society]. Tokyo: Chikuma Shobō.

Yamada, Masahiro. 2009. Wākingu pua jidai: Soko-nuke seifuti-netto o saikōchiku seyo [Era of working poor: Rebuild the failing safety net]. Tokyo: Bungei Shunju.

Yomirui Online. 22 April 2010. "Ima no kaisha ni isshō tsutometai" kako saikō $57.4 \%$ ["I want to work at my present company for my entire life," highest on record at 57.4\%]. http://www.yomiuri.co.jp/kyoiku/news/20100422-OYT8T00534. htm (accessed on 3 October 2010). 